öz

İç mimarların temel çalışma alanlarından birini de inşa edildikleri dönemdeki işlevlerini yitirmiş yapıların yeni kullanım koșulları ve gereksinimleri doğrultusunda yeniden işlevlendirilmesi oluşturmaktadır. Yeniden ișlevlendirilen yapılar yakın zamanda inşa edilmiş yeni yapılar olabildiği gibi işlevini yitirmiş ancak korunması gerekli kültür varlığı yapılar da olabilmektedir. Kültür varlıklarının korunabilmesi ve gelecek nesillere ulaştırılabilmesi ancak bu konuda bir hassasiyetin geliştirilmesiyle sağlanabilir. Tasarım alanında çalıșan tüm meslek grupları gibi iç mimarların da kültür varlıklarının korunması konusunda farkındalıkları yüksek olmalıdır. İc mimarların koruma bilinci konusunda kendilerini geliștirmelerinde en önemli basamak lisans eğitimidir.

Çalışma kapsamında; Özyeğin Üniversitesi, Mimarlık ve Tasarım Fakültesi, İç Mimarlık ve Çevre Tasarımı Bölümü'nde 2019-2020 bahar yarıylında gerçekleştirilen Mezuniyet Projesi incelenmiş, öğrencilerin tarihi bir yapı için yeniden işlevlendirme önerileri üzerinden koruma bilinci ve eğitim ilişkisi değerlendirilmiştir. Öğrencilerin lisans eğitim programlarında zorunlu ve seçmeli olarak yer alan tarihi yapıların korunmasına yönelik derslerde edindikleri bilgi birikimlerini, tarihi bir yapı ile karşı karşıya kaldıklarında pratiğe aktarabilme becerileri sorgulanmıștır.

Öğrencilerin yaklaşımlarını analitik bir şekilde değerlendirebilmek adına; teslim edilen projeler tarihi yapıyla kurulan ilişkide olması gereken hassasiyetler ve kriterler üzerinden tanımlanan dört farklı seviyeye göre analiz edilmiștir. Proje analiz çalışmalarının yanı sıra derse kayıtlı olan ögrencilerden dönem sonunda mezuniyet stüdyosu deneyimlerini değerlendirdikleri bi metin yazmaları istenmiștir. Toplanan metinler önce kullanım sıklıklarına göre etiket bulutu (tag cloud) ile incelenmiş, ardından iki farklı araştırmacı tarafindan ana olguların belirlendiği içerik analizi çalıșması yürütülmüş̧ür.

Yapılan değerlendirmelere göre ortak yönelimler ve farklı yaklaşımlar ortaya konmuștur. İç mimar adaylarını meslek hayatlarında karşılaşmaları olası olan tarihi yapıların yeniden işlevlendirmesi üzerine donanımlı hale getirmek için öneriler sunulmuştur.

Anahtar Kelimeler: Koruma, yeniden işlevlendirme, iç mimarlık eğitimi.

\section{Iç Mimarlık Eğitiminde Koruma Bilincinin Geliştirilmesine Bir Katkı: Mezuniyet Projesi Örneği}

(iD) Selin $\ddot{U}$ st Özyeğin Üniversitesi Mimarlık ve Tasarım Fakültesi, İç Mimarlık ve Çevre Tasarımı Bölümü, Istanbul, Türkiye

\author{
(iD) Ayşe Ceren Güler \\ Özyeğin Üniversitesi Mimarlık ve Tasarım Fakültesi, Mimarlık Bölümü, İstanbul, Türkiye
}

Başvuru tarihi/Received: 03.10.2020, Kabul tarihi/Final Acceptance: 29.07.2021

\section{Extended Abstract}

One of the main interest areas of interior architects is the adaptation of buildings which have lost their authentic functions that they were built for, to new uses, conditions and requirements. These buildings may not be only the new ones but also the historic buildings that are listed as a cultural heritage and have to be preserved. Conservation of cultural heritage and transmitting it to the future generations can only be achieved by raising sensitivity to this value. Therefore, interior architects should enhance their awareness of the conservation of cultural heritage just like all members and groups working in the field of architectural design. It is certain that undergraduate education is one of the most important steps in the development of interior architects' awareness of conservation.

The present study aims to discuss the importance of developing an understanding of conservation in interior architecture education. Firstly, Ozyegin University, Faculty of Architecture and Design, Department of Interior Architecture and Environmental Design undergraduate curriculum was examined to figure out the percentage of theoretical conservation courses in interior design education. This evaluation brought to mind the question if the theoretical knowledge has been reflected in practice or not. Because the graduation studio is the last step before entering professional life, students are expected to demonstrate their skills in interior design by integrating their knowledge from the undergraduate programme. In the view of conservation awareness; the students have to apply their knowledge of conservation that they have learnt throughout the theoretical courses and apply such knowledge in their projects. Therefore, the student works of 2019-2020 Spring Semester Interior Architecture Graduation Studio in which students were expected to create adaptive reuse proposals for a historic building-Paşaliman Flour Factory-have been evaluated through the relationship between the awareness of conversation and the interior architecture education. With the resources directed about the subject and seminar series and technical trips organized throughout the term, it is aimed that the students would perceive the historical texture in which the historic building is located better, become aware of the unique and need to be protected values of the environment, and enrich their perspectives in order to emphasize these values in their design they would develop.

Within the scope of the study, student projects submitted at the end of the semester were examined in terms of the differences in the approach to the historic building and the priorities for preservation. In order to evaluate students' approaches analytically, the projects were analyzed according to the four different levels defined on the criterion that should be in relation with the historic monument. The extent to which the design proposals made by the students met the criterion was analyzed through the scoring system. In addition to this, at the end of the semester the students who enrolled in the graduation studio were asked to write texts in which they evaluated their studio experiences. The collected texts were first examined for the frequency of the words used via a cloud analysis, and then a content analysis study was conducted by two independent researchers to discover the concepts and relations. In addition to the observations made throughout the term, these analytical analyses based on the projects and collected texts at the end of the term provided important and comparable data for the study.

In conclusion, the common tendencies and different approaches of the students to the historic monument were revealed according to the assessments. Although all of the students have developed a sensitivity for conservation, most of them mentioned the difficulties in transferring the theoretical knowledge of conservation to reuse practice. It is important to support the interior design students not only within the scope of the studio course but throughout their education life in order to increase the awareness of conservation. In this direction, it is necessary to increase students'awareness on conservation with the help of compulsory and elective courses that can be added to their undergraduate curriculum. In addition, it would be beneficial for students to experience adaptive reuse interior design projects related to a historical building that they may encounter in their professional lives, not only in the graduation studio, but also in the other studio classes before reaching this stage, on different scales and requirements.

Keywords: Conservation, reuse, interior architecture education. 


\section{Giriş}

Zengin bir kültür mirasına sahip olan ülkemizde kültürel sürekliliğin sağlanabilmesi, tarihi çevrenin korunması ve gelecek kuşaklara aktarılabilmesi görevi çoğunlukla tasarım ve planlama alanında çalışan uzmanlara düşmektedir. Bu alanda çalışan mimar, iç mimar, peyzaj mimarı, şehir plancı gibi uzmanların tarihi çevre konusunda farkındalıklarının yüksek, koruma bilinçlerinin gelişmiş olması bu çevrelerin sürdürülebilirliğinin sağlanması açısından son derece önemlidir.

İç mimarlık pratiği ağırlıklı olarak mevcut binaları yeni kullanımlara ve gereksinimlere uyarlamak ile ilgilenmektedir. Zamanının işlevsel ihtiyaçlarını karşılamak için inşa edilen yapılar, sosyal yaşamdaki değişiklikler ve kültürel ve sosyo-ekonomik koşulların değişmesine ilişkin ihtiyaçlar nedeniyle işlevsiz hale gelebilmektedir. İşlevini yitirmiş ancak fiziksel varlığını koruyan bu yapıların, değerlerini geleceğe aktarabilmeleri için "yeniden kullanım" açısından değerlendirilmesi önem taşımaktadır. Her yapı yapıldı ğ döneme dair sosyal ve kültürel izler taşımaktadır. Yeniden işlevlendirme tarihsel, kültürel, anıtsal ve çevresel değerleri korumak ve bu değerleri geleceğe aktarmak için koruma alanında karşımıza çıkan müdahale yöntemlerinden biridir.

İç mimarlar meslek hayatları boyunca yeniden işlevlendirme odaklı pek çok projede görev alırken, karşı karşıya kaldıkları yeniden değerlendirilmesi gereken yapıların bir bölümü korunması gerekli kültür varlığı yapılar olmaktadır. İç mimar adaylarının kültür varlıklarıyla koruma çerçevesinde kurduğu doğru ilişki ve hassasiyetin mezun olmadan, henüz öğrenim aşamasında geliştirilmesi önemlidir. Bu noktada tasarım eğitimi ve tasarım eğitiminde tarihi dokuda gerçekleştirilen çalışmaların önemi ön plana çıkmaktadır.

Bu çalışmada; iç mimar adaylarının öğrenim hayatları boyunca edindikleri teorik bilgi birimlerini koruma ile ilgili bir uygulama ile karşı karşıya kaldıklarında pratiğe dökme durumu Özyeğin Üniversitesi, İç Mimarlık ve Çevre Tasarımı Bölümü mezuniyet projesi çıtıtıarı üzerinden tartış1mıştır. Çalışma kapsamında, 2019-2020 bahar yarıyılı mezuniyet projesi işleyiş süreci ve çıktıları ile ele alınmış; teslim edilen öğrenci projeleri kültür varlığı bir yapıya yaklaşımda belirlenen öncelikli kriterler doğrultusunda değerlendirilmiştir. Bununla beraber; sürecin sonunda öğrencilerden mezuniyet stüdyosunda gerçekleştirdikleri projeyle ilgili deneyimlerini paylaştıkları metinler yazmaları istenmiştir. Metinler incelenmiş, öğrencilerin deneyimlerinden faydalanarak mezuniyet stüdyosunun koruma bilinci gelişimine katkısı üzerine değerlendirme yapmak amaçlanmıştır.

\section{1. İç Mimarlık Lisans Eğitiminde Koruma}

İç Mimarlık eğitimi, zaman ve süreklilik gerektiren stüdyo tabanlı bir öğrenimdir. Tasarım stüdyosu; stüdyodaki öğrenme deneyimi üzerinden öğrencilerin ortaya çıkan problemleri çözmeye odaklandığı, yeni anlama biçimleri geliştirdiği, duyumladıklarını bilgiye yansıttığı yer olarak ifade edilmektedir (Salama 1995; Salama 2015; Schön 1985; Schön ve Wiggins 1992). İç mimarlık öğrencileri, ilk stüdyodan başlayarak mezuniyet stüdyosuna kadar her dönem farklı ölçeklerdeki tasarım problemleri için çözüm önerileri geliştirmektedir. Stüdyo dersleri mekân bilgisi, mobilya, ergonomi, yapı bilgisi ve malzeme, detay, statik-mukavemet, fiziksel çevre kontrolü, rölöve, sürdürülebilir tasarım anlayışı gibi teorik ve uygulamalı derslerle desteklenmektedir. Ancak; diğer tasarım disiplinleri ile benzer şekilde iç mimarlık eğitiminde karşılaşılan temel problemlerden biri de öğrencilerin öğrenim hayatı boyunca teorik ve uygulamalı derslerden edindiği bilgi birikimini stüdyodaki tasarımlarına ve gerçek hayata aktarmakta yaşadıkları zorluklardır. Aynı problem; tarihi çevre koruma, kültür varlıklarının korunması gibi koruma ve tasarım temalarının bir arada tartışıldı noktalarda da ortaya çıkmaktadır (Ahunbay vd. 2002). Stüdyo derslerinde özgün tasarım öncelikli yaklaşım sergileyen öğrenciler, tasarımın çok boyutlu yapısını göz ardı edebilmektedir. Öğrencilerin büyük çoğunluğu tasarımlarını geliştirirken, 
çalışmalarını yürüttükleri tarihi çevreye ait sürdürülmesi gereken fiziksel özellikler ile yeniden işlevlendirdikleri tarihi yapının korunması gereken özgün değerlerini bir arada değerlendirmekte zorlanmaktadır. Oysa ki; her bir mimari yapının bağlamı, bulunduğu kent ve yakın çevresi iken, her bir iç mekânın bağlamı da içinde bulunduğu yapı olduğuna göre tarihi çevrenin kent ölçeğinden başlayarak iç mekân ölçeğine kadar devamlı bir yaklaşımla analiz edilmesi gerekliliği kaçınılmazdır (Onay 2015, 194).

Koruma konusunda aktarılan bilgilerin öğrenciler tarafından stüdyo derslerine yeterince yansitılamama problemi ülkemizde pek çok farklı çalışmanın ortak konusu olmuştur. Karsl ve Fitoz (2018, 127-129), lisans programlarında koruma teorisinin öğretildiği pek çok ders olmasına rağmen öğrencilerin bu bilgiyi tasarım fikrine dökmekte problem yaşadıklarını belirtmişlerdir. Karakök ve Gökarslan (2017, 54), iki farklı üniversitenin mimarlık öğrencilerinin katılımıyla tarihi dokuda çağdaş ek tasarımı konulu bir atölye çalıșması düzenlemişlerdir. Çalıșma sonucunda; öğrencilerin korumaya dair edindikleri kuramsal bilgiyi pratiğe yansıtabilmeleri için stüdyo yürütücülerinin öğrencileri daha fazla reel çalışma alanlarına özgü proje tasarlamaya yönlendirmeleri gerektiği tespit edilmiştir (Karakök ve Gökarslan 2017, 77-78). Bu nedenledir ki; ülkemizdeki çeşitli üniversitelerin iç mimarlık bölümlerinde koruma temalı gerçekleştirilen çalışmaların sayısı gitgide artmaktadır. Onay ve Yazıcıoğlu (2015, 674-675), İTÜ Mimarlık Fakültesi İç Mimarlık Bölümü'nde 6. dönem stüdyosu kapsamında gerçekleştirdikleri Ali Paşa Hanı'nın yeniden işlevlendirmesi projesi deneyimlerine göre tarihi yapıya müdahalede kültürel anlamın korunması için ana tasarım kriterinin kamu yararı gözeterek sosyal açıdan uygun işlevin belirlenmesi olduğunu savunmaktadırlar. Karakul (2018, 140), Selçuk Üniversitesi İç Mimarlık Bölümü'nde stüdyo kapsamında öğrencilerin somut olmayan kültürel miras ve yeniden kullanım kavramları üzerine yoğunlaşarak Konya'da bulunan bir 19. yüzyıl yapısı olan Tantavi Ambarı'nı Türkiye'nin somut olmayan kültürel miras müzesine dönüştürülmesine yönelik tasarım yaklaşımlarını paylaşmıştır. Öğrencilerin tarihi bir yapıya yaklaşım konusunda farkındalıklarını arttırmak amacıyla Selçuk Üniversitesi İç Mimari Proje stüdyosunda Konya Öğretmen Lisesi yapısı verilmiş kültürel mirası koruma ve tasarım stüdyosu arasında ilişki kurmak amaçlanmıștır (Karakul 2018, 140141).

Uluslararası ölçekte ise koruma bilgisini pratiğe dökmek için en verimli yerin stüdyo öğrenimi olduğunu savunan çalışmalar oldukça yaygındır (Embaby 2014, 339-350; Kapp vd. 2014, 175-177; Clarke vd. 2019, 67-75) Bu tür çalışmalarda, mevcut doku ve yapıya yabancılaşmadan yeni fonksiyonlar ekleyerek farklı zaman dilimlerine ait form ve malzemelerin bir araya getirilme biçimleri üzerine odaklanmak ana ilkeyi oluşturmaktadır (Sanza 2015, 440). Bununla beraber, stüdyo içindeki çabanın koruma bilinci oluşumuna etkisinin yetersiz olduğunu savunan çalışmalar da bulunmaktadır (Orbasli ve Whitbourn 2002, 67; Wells 2018, 466) Koruma bilinci farkındalığını stüdyo sürecine dahil etmenin zorlukları üzerine değinen bu yayınlarda, stüdyoda gerçekleştirilen projelerin ana odağının tarihi çevre ve koruma olmaktan ziyade tasarım geliştirme süreci olduğu vurgulanmaktadır (Wells 2018, 467). Jokilehto (2007, 285)'a göre; koruma bilinci öğrenimini tek bir stüdyo dersi ile sınırlamak değil, öğrencinin lisans eğitimi boyunca sürekliliği olan metodolojik bir yaklaşım ile desteklemek gerekmektedir. Yaklaşım dahilinde; öğrencilerden çalış1lan yapının öznel değerlerini ve kültürel, sosyo-ekonomik ve çevresel bağlamını dikkate alarak eleştirel düşünme becerisini geliştirmeleri beklenmelidir.

\section{2. Özyeğin Üniversitesi İç Mimarlık ve Cevre Tasarımı Bölümü Lisans Eğitiminde Koruma}

Özyeğin Üniversitesi Mimarlık ve Tasarım Fakültesi İç Mimarlık ve Çevre Tasarımı Bölümü mezuniyet stüdyosunda her dönem iç mimar adaylarının sürdürülebilirlik ilkelerini tasarım sürecine dahil ederek tarihi bir yapıyla koruma çerçevesinde doğru bir ilişki kurmaları beklenmektedir. Öğrenciler 
ilk kez karşı karşıya kaldıkları bu problemle başa çıkmakta oldukça zorlanmaktadır. Oysa ki; İç Mimarlık ve Çevre Tasarımı lisans programında koruma alanında iki adet zorunlu ders bulunmaktadır. Architectural Conservation and Surveying (Mimari Koruma ve Rölöve) dersinde kültür varlı̆̆ kavramı ve koruma ölçütleri, koruma düşüncesinin tarihsel gelişimi, tarihi yapıdaki bozulma nedenleri, müdahale teknikleri, tarihi çevre koruma, ulusal ve uluslararası yasal düzenlemeler ve örgütler konularında bilgi sahibi olabilecekleri teorik ve uygulamalı bir öğrenim gerçekleştirilmektedir. Aynı dönem programın diğer bir zorunlu dersi olan Details for Interiors II: Adaptive Re-use (İ̧̧ Mimari Detayları II: Yeniden Işslevlendirme) dersinde ise mekânların yeniden işlevlendirilmesinde sıklıkla karşılaşılan detay sorunları ve çözüm yöntemleri üzerinde durulmaktadır.'

Ancak bölümün lisans programında öğrenciyi doğrudan işin içine katarak proje üretmesinin sağlanabileceği stüdyo derslerinde koruma odaklı iç mekân projelerine verilen ağırlık mezuniyet projesi ile sınırlıdır. ${ }^{2}$ Öğrencilerden mezuniyet projesine gelene kadar koruma alanında edindikleri bilgi birikimini birleştirip bir sonuç elde etmeleri beklenmemektedir. Meslek hayatından önceki son adım olan mezuniyet stüdyosunda ise, iç mimar adayı olan öğrencinin tüm öğrenim sürecinde edinmiş olduğu bilgi ve deneyimlerini kullanarak verilen tarihi yapıya yeni bir işlev yüklemesi istenmektedir. Öğrencilerin mevcut yapının tarihi değeri ve geleceği arasında bağ kurarak iç mimari tasarım problemini bütünleşik bir yaklaşımla çözmesi arzu edilmektedir.

Kültür varlığı bir yapıya yapılacak müdahalenin kapsamı belirlenirken yapının tarihi ve kültürel arka planını anlamak önemlidir. Bu nedenle yeniden işlevlendirme için tasarım önerileri geliştirmeye başlamadan önce, öğrencilerin yapıların mimari ve mekânsal potansiyelini analiz edilebilecek farkındalığa ulaşmasının sağlanması gerekir. İç mimarların temel çalışma alanlarından biri olan yeniden işlevlendirme konusundaki yetkinliğini tarihi çevre ve korunması gerekli kültür varlıkları alanında da geliştirebilmeleri ancak lisans eğitimleri boyunca edindikleri koruma bilinci sayesinde gerçekleşebilir. Bununla birlikte bu gelişime katkı sağlayacak önemli adımlardan biri de lisans eğitimlerindeki uygulamalı derslerde tarihi yapı ile doğrudan ilişki kurabilecekleri daha fazla sayıda örnek üzerinde çalışmalarına olanak sağlamaktır. Aksi takdirde; iç mimarlık lisans öğrencileri öğrenimleri süresince birçok kez tarihi doku, tarihi yapı ve koruma temalı sunumlar izlemelerine rağmen tarihi doku ile ilişki içerisinde tasarım geliştirme ve bulundukları çevrenin özelliklerinin farkında olma konusunda sıkıntı yaşamaktadırlar.

\section{3. Özyeğin Üniversitesi İç Mimarlık ve Çevre Tasarımı Bölümü Mezuniyet Projesi Örneği: Paşalimanı Un Fabrikast}

2019-2020 Bahar döneminde Özyeğin Üniversitesi İç Mimarlık ve Çevre Tasarımı bölümü mezuniyet projesi stüdyosunda iç mimar adaylarından tescilli tarihi bir yapıyı kültürel faaliyetlere yönelik bir program dahilinde yeniden işlevlendirmeleri istenmiştir. Tarihi bir yapının mevcut durumunun belgelenmesi; alan çalışması ile yapılan ölçüm ve araştırmaların ardından çizim aşaması da düşünülecek olursa oldukça uzun bir süreç gerektirdiğinden ögrencilere rölöve çizimleri hazır olan bir yapı örneğinin verilmesi tercih edilmiştir. Bu çalışma için Üsküdar Paşalimanı Caddesi üzerinde, sadece dış duvarları ayakta olan, tarihi Paşalimanı Un Fabrikası belirlenmiştir (Şekil 1, Şekil 2, Şekil 3, Şekil 4).

Paşalimanı Un Fabrikası, Paşalimanı Dakik Fabrikası adı ile de anılmaktadır (Kariptaş 2012, 109). 19.yüzyıla ait önemli bir endüstri yapısı olan un fabrikası uzun yıllar kullanıldıktan sonra işlevini yitirmiştir. Gayrimenkul Eski Eserler ve Anıtlar Yüksek Kurulu tarafindan I. derece eski eser olarak tescil edilmiş olan yapı, 1883 'de çıkan bir yangın sonrasında İstanbul'da ihtiyaçtan fazla sayıda değirmen olduğu gerekçesiyle onarılmamıştır (Müller-Wiener 1992, 54). Mevcut değirmenler kentin un ihtiyacını karş1lamakta yetersiz kalınca, yapı yenilenerek 1910 yılında tekrar kullanıma açılmıştır.

\footnotetext{
Özyeğin Üniversitesi, Iç Mimarlık ve Ceure Tasarımı Bölümü Ders İ̧erikleri. Erişim Adresi: https://www.ozyegin.edu.tr/tr/ ic-mimarlik-ve-ceure-tasarimi/lisans/ ders- icerikleri.

2 Aynı erişim adresinden stüdyo derslerinin işerikleri görüntülenebilmektedir.
} 
Şekil: I

Paşalimanı Un Fabrikası'nın mevcut durumunu gösteren fotoğraf.

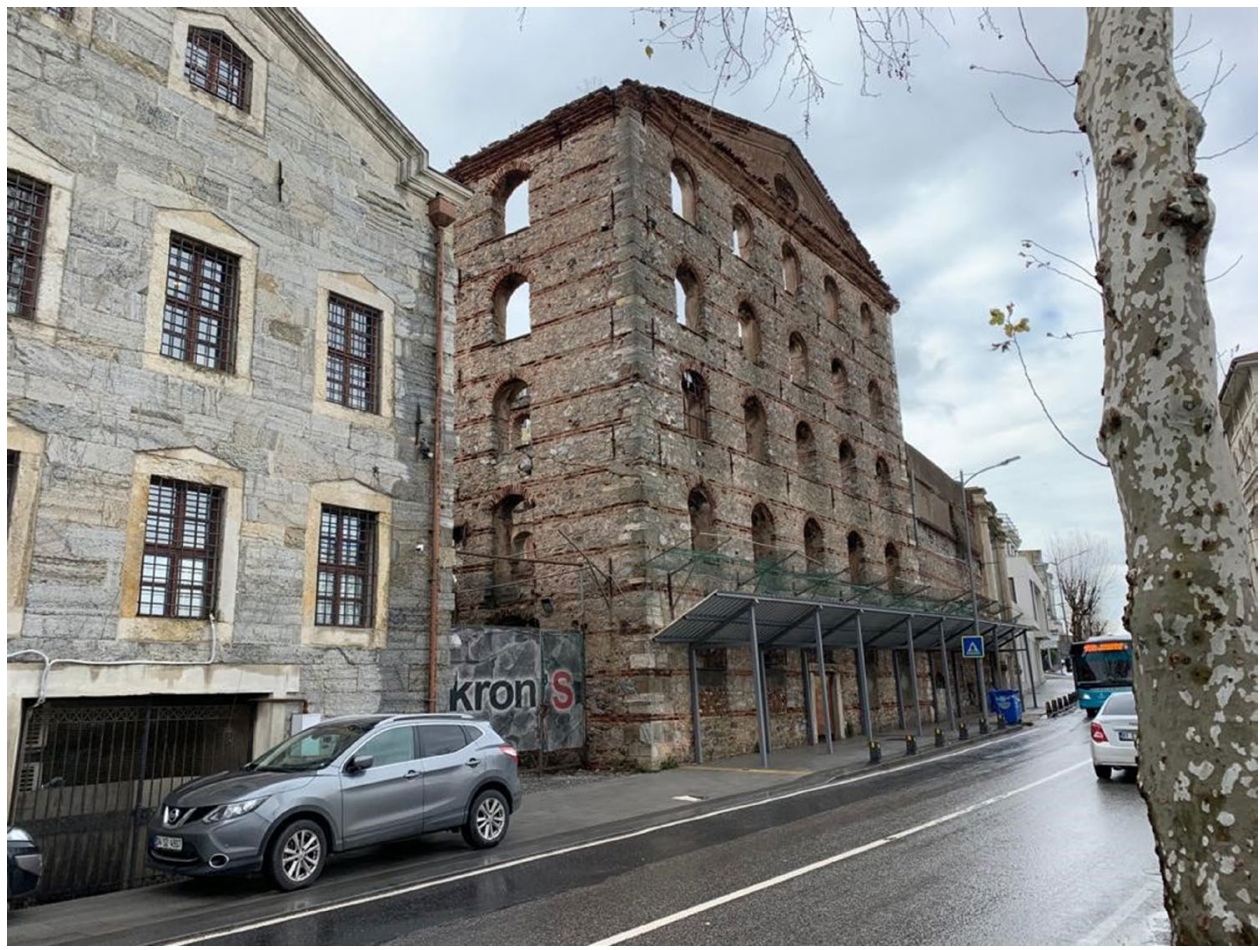

Sekil: 2

Üsküdar- Paşalimanı Pervititch Haritası.

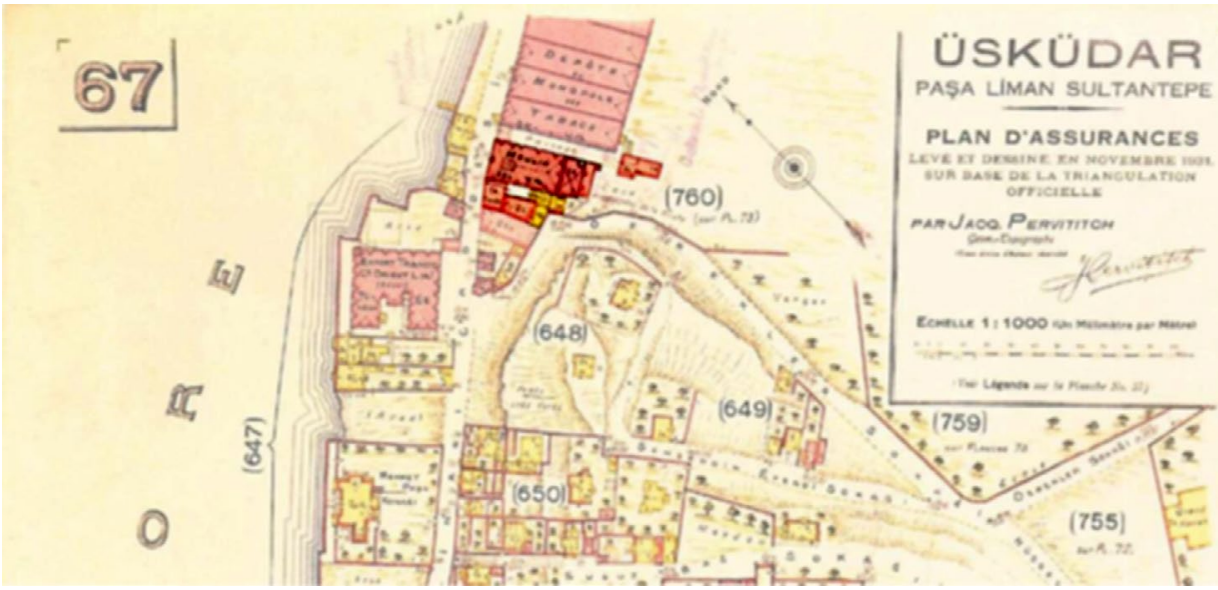

20. yüzyılın başında kiraya verilen yapı, 1920 yılından sonra İttihat Değirmencilik Anonim Şirketi tarafindan kullanılmaya başlanmış ve 1940 yılına kadar faaliyetlerini sürdürmüştür. 1940'dan itibaren kullanılmayan tarihi yapı günümüzde oldukça bakımsız ve harap durumdadır (Kariptaş 2012, 113; Müller-Wiener 1992, 53).

Anıtların hayatını sürdürebilmesi ve korunması toplumsal bir amaç için kullanarak kolaylaştırılabilir (Venedik Tüzüğü 1964). $\mathrm{Bu}$ amaçla günümüzde ișlevini yitirmiş tarihi bir yapının bu türden bir amaç için kullanılmak üzere yeniden işlevlendirilme- si istenir. Yeniden işlevlendirmede dikkat edilmesi gereken temel unsurlardan biri verilen yeni işlevin kültür varlığı yapının özgünlüğüne ve bütünlüğüne, özgün plan şeması, malzemesi vb. özelliklerine zarar vermeyecek nitelikte olmasıdır. $\mathrm{Bu}$ noktada stüdyo konusunun stüdyo yürütücüsü tarafından en başından belirlenmesi öğrencilerin tarihi yapıya yaklaşımlarını sürecin bașından itibaren yönlendirmiștir. Tarihi un fabrikasının performans merkezi olarak yeniden işlevlendirilmesinin öngörülmesi yapının burayı ziyaret etmek isteyen herkese açık, kültürel bir amaçla 

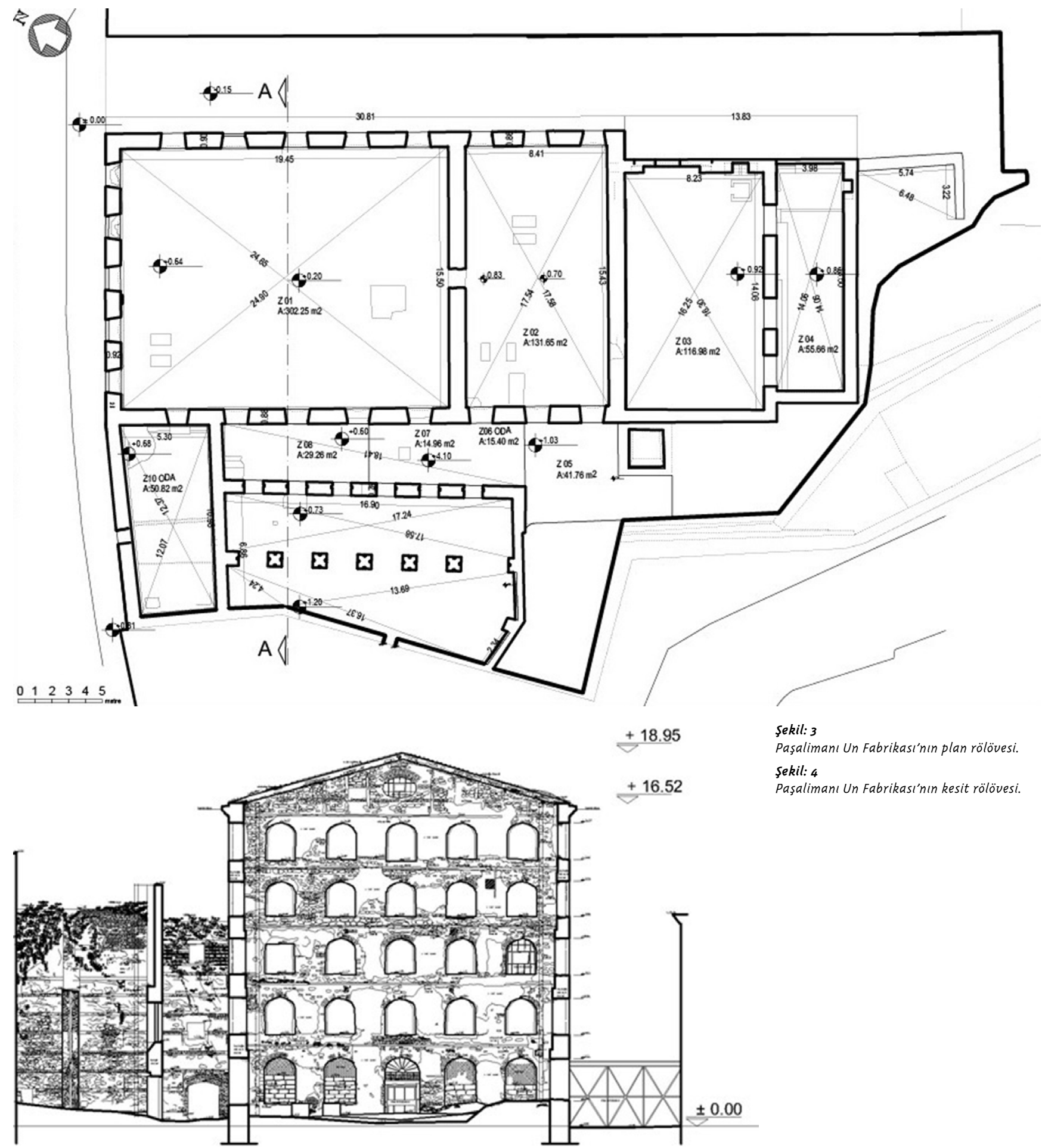

kullanılmasına olanak sağlayacak bir seçenek olması bakımından tercih edilmiştir. Mezuniyet projesi kapsamında; sanatın farklı dallarına ev sahipliği yapan bir üretim merkezi olarak öngörülen performans merkezi başlığı altında, öğrencilere verilen iş programına göre yapıda bir adet 150 kişi kapasiteli çok amaçlı salon, fuaye alanı, en az bir adet müzik-kayıt stüdyosu, en az bir adet dans stüdyosu, ihtiyaca yönelik giyinme-soyunma odaları, yönetim ofisleri, kafeterya, mutfak ve depolama hacimlerini 
Tablo: I

Özyeğin Üniversitesi, Mimarlık ve Tasarım Fakültesi, Iç Mimarlık ve f̧evre Tasarımı Bölümü, 2019-2020 Bahar Dönemi Mezuniyet Projesi seminerleri. tasarlaması beklenmiştir. Tarihi yapının yeniden kullanımında işlev ile mekân arasındaki ilişkisinin nasıl kurulacağı, yeni işlevin gerektirdiği iç mekândaki değişikliklerin neler olacağı, iç mekân tasarımının koruma anlayışı ile nasıl uyum sağlayacağı sorularının cevapları öğrencilerin sunduğu çözümlerde aranmıştır.

Stüdyo yürütücüsü gerek dönemin ilk dersinde öğrencilere yaptığ 1 sunum gerekse yönlendirdiği kaynaklar ile öğrencilerin yapıyla ilgili detaylı bilgi sahibi olmalarını amaçlamıştır. İlk hafta öğrenciler ile okumalar üzerinden yapılan tartışmalar sonrasında, öğrencilerin yapı ve yakın çevresine yapılan arazi gezisiyle çevreyi deneyimlemeleri hedeflenmiştir. Bölgeye yapılan teknik gezide öğrenciler, Üsküdar-Kuzguncuk hattında gözlem yapma ve belgeleme, yapının güçlü ve zayıf yönlerine dair yerinde değerlendirmede bulunma ve projeleri için olabilecek firsat ve tehditleri saptama şansı yakalamışlardır. Dönem başında gerçekleştirilen gezi ile öğrencilerin yapının bulunduğu tarihi dokuyu daha iyi algılamaları, çevrenin özgün ve korunması gerekli değerlerinin farkına varmaları ve geliştirecekleri tasarımda bu değerleri vurgulayabilmek için bakış açılarını zenginleștirmeleri hedeflenmiştir.

Dönemin ikinci haftası düzenlenen seminer dizisiyle öğrencilerin hem endüstri mirasının korunması ve yeniden işlevlendirilmesi üzerine daha önce aldıkları teorik bilgiyi canlandırmak hem de gerçekleştirilmiş çağdaş örnekler görmelerini sağlayarak farkındalıklarını artırmak amaçlanmıştır. $\mathrm{Bu}$ kapsamda alanında uzman öğretim üyeleri ve profesyoneller stüdyoya davet edilerek farklı konularda seminer vermeleri istenmiştir. Seminerler için davet edilen konuklar ve sunum başlıkları Tablo 1'de görülmektedir.

İç Mimarlık ve Çevre Tasarımı Bölümü Mezuniyet projesi, öğrencilerin lisans eğitimi boyunca tamamladıkları diğer iç mimarlık stüdyoları ile benzer şekilde yürütülmektedir. Tüm öğrencilerin Pazartesi ve Perşembe gerçekleşen stüdyo derslerine katılmaları ve stüdyoyu bir öğrenme mekânı olarak kullanmaları beklenmektedir. Stüdyo yürütücüsü dönem boyunca haftada iki yarım gün olan stüdyo saatlerinde öğrencilerle bir araya gelerek projeleri-

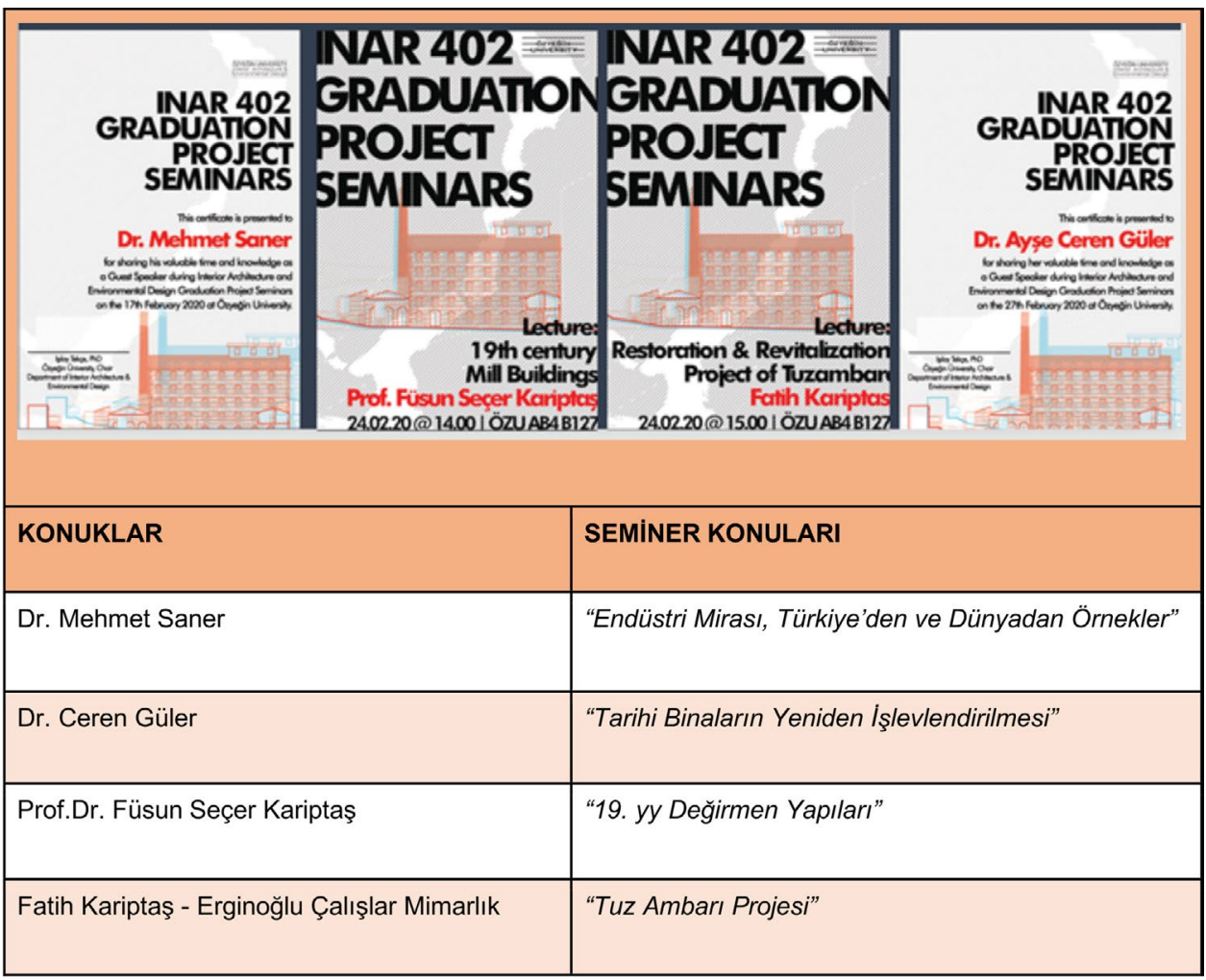


nin gelişimini tartışmaktadır. Öğrenciler dönem boyunca geliştirdikleri fikirler üzerinden dersin yürütücüsü ile yaptıkları görüşmelerin yanı sıra belirli aralıklarla toplanan jürilerde de jüri üyelerinden kritik alma firsatını yakalamışlardır. Mezuniyet projesinde öğrencilerin dönem içinde en az iki ara jüriye ve bir final jürisine katılımları beklenmektedir. Öğrencilerin verilen problem için geliştirdikleri çözüm önerilerini anlatmak üzere hazırladıkları çizim ve maketler ile sınıf arkadaşlarının ve jüri üyelerinin önüne çıtığ 1 jüriler iç mimarlık eğitiminin önemli bir parçasıdır. Ara jüriler, öğrencilerin tasarımlarıyla ilgili geri bildirim aldıkları ve çalışmalarını nasıl geliştireceklerini dair ipucu buldukları öğrenme deneyimleri iken; final jüri, jüri üyelerinin projenin başarılı olup olmadığına karar verdikleri son adımdır.

\section{9-2020 bahar dönemi mezuniyet} projesinde öğrencilerden, kendi bağlamı içinde karmaşık ve çok boyutlu tasarım problemleri içeren mekân sistemlerini tasarlaması, yaşam güvenliği çözümleri üretmesi, bina servis sistemlerini iç mekân programıyla bütünleştirmesi beklenmiştir. Bununla beraber; öğrencilerin tarihi bir yapının iç mekânını bütünleşik bir yaklaşımla ele almaları ve dolayısıyla kültür varlığı yapıların korunması konusundaki farkındalıklarının artarak, bu alanda disiplinlerarası çalışmanın önemini kavramaları hedeflenmiştir. Bu noktada; iç mimarların farklı meslek gruplarından uzmanlar ile birarada ve uyum içerisinde çalışmaları gerekliliği ortaya çıkmaktadır. Böyle bir örnekte, farklı mesleklerden kişilerin kendi uzmanlık alanları çerçevesinde daha etkin karar alabilmeleri, ortak konunun farklı noktalardaki hassasiyetleri hakkında bilgi sahibi olmalarını gerektirir. Konunun çok disiplinli bir yaklaşım gerektirdiği öngörüsüyle, jüri üyeleri belirlenirken de iç mimarlık öğretim üyeleri ile birlikte mimarlık öğretim üyelerinden de oluşan bir ekip oluşturulmasına özen gösterilmiştir. Disiplinler arası işbirliğine önem verilerek jüri üyeleri arasında mimarlık tarihi ve koruma gibi farklı alanlardan, alanında uzman akademisyenlerin bulunmasına dikkat edilmiştir.

\section{1 Çalışmanın Yöntemi}

İç Mimarlık ve Çevre Tasarımı Bölümü mezuniyet projesi tarihi bir yapının yeniden işlevlendirilmesi tasarım problemi üzerine odaklanması nedeniyle, iç mimarlık eğitiminde korumanın yerini tartışmayı hedefleyen bu çalışmanın çıkış noktasını oluşturmuştur. 2019-2020 bahar dönemi başında 17 öğrencinin kayıt olduğu mezuniyet projesini 15 öğrenci başarılı not alarak tamamlamıştır. Çalışma kapsamında; öncelikli olarak 15 öğrenci tarafından teslim edilen projeler, tarihi yapıya yaklaşımdaki farklılıklar ve korumaya yönelik öncelikler açısından incelenmiştir. Söz konusu değerlendirme için; kültür varllğg 1 yapı ile kurulan ilişkide olması gerekli temel kriterler tanımlanmış, öğrenciler tarafından getirilen önerilerin bu kriterleri ne ölçüde karşıladığg puanlama sistemi üzerinden analiz edilmiştir. Bununla birlikte, dönem sonunda derse kayıtlı olan her öğrenciden mezuniyet stüdyosu deneyimini paylaştığı değerlendirdikleri bir metin yazması istenmiştir. Toplanan metinler önce kullanım sıklıklarına göre etiket bulutu (tag cloud) ile incelenmiş, ardından iki farklı araştırmacı tarafından ana olguların belirlendiği içerik analizi çalışması yürütülmüştür.

Yapılan çalışmada; proje analizi ve öğrencilerin süreci değerlendirdikleri metinler birlikte ele alınarak tarihi yapıya yönelik benzer veya farklı yaklaşımlar ortaya konulmuştur.

\section{$3.2 \quad$ Analiz Yöntemleri}

\subsubsection{Projelerin Analizi}

Öğrencilerin öğrenim süresince edindikleri bilgi birikimlerinin yanı sıra dönem boyunca jürilerde sundukları önerileri üzerinden yapılan değerlendirmelerde; kendilerine tarihi yapının günümüze ulaşmayı başarabilen özgün dokusunun korunması gerektiğinin önemi sıklıkla hatırlatılmıştır. Tarihi yapı yeniden işlevlendirilirken özgün plan şeması ve kurgusu ile uyumlu bir öneri geliştirilmesi, özgün niteliklerine zarar verecek ağır bir müdahaleden kaçınılması gerektiği vurgulanmıştır. Her öğrencinin performans merkezi konusu özelinde kendi 
Tablo: 2

Mezuniyet stüdyosunda teslim edilen projelerin belirlenen öncelikli kriterler bağlamında tarihi yapı ile kurduğu iliş̧ki analizi. iş programını oluştururken bu hassasiyetlere dikkat etmesi beklenmiştir. Geleneksel yapım tekniklerini tekrar ederek bir uygulama gerçekleştirmenin veya modern yapım tekniklerini tercih etmenin birer tercih olabileceği aktarılırken, farklı tercihlerin tarihi yapıya getirdikleri üzerinden değerlendirmelerde bulunulmuştur. Yapının tarihsel gelişim sürecinin, özgün işlevinin, geçmiş̧e yapıda gerçekleştirilen endüstriyel üretim sürecinin ve süreci anlatan teknik donanımlarının ve izlerinin yapının önemli bir parçası olduğu ve korunması gerektiğinin altı çizilmiştir.

Öğrencilerin yaklaşımlarını analitik bir şekilde değerlendirebilmek adına; teslim edilen projeler tarihi yapı ile kurulan ilişkide olması gereken hassasiyetler ve kriterler üzerinden tanımlanan dört farklı seviyeye göre analiz edilmiştir.

Değerlendirme aşamasında göz önünde bulundurulan kriterler; önerilen tasarımın tarihi yapının özgün dokusunu koruma yaklaşımı, müdahale ölçeği, yapının özgün işlevine yönelik endüstriyel üretim sürecinin yeni kullanımda yansıtılması, yapının özgün plan şeması, kurgusu, malzeme ve yapım teknikleri ile uyumlu tasarım yapılması olarak belirlenmiştir. Bununla birlikte müdahale aşamasında geleneksel yöntemlerin mi yoksa modern malzeme ve yapım sistemlerinin mi tercih edildiği de göz önünde bulundurulmuştur.

Belirlenen öncelikli kriterler doğrultusunda öğrencilerin mezuniyet projelerinde çalışma konuları olan tarihi yapı ile kurdukları ilişki analizi sonuçlarına aşağıdaki tabloda yer verilmiştir. Teslim edilen 15 farklı proje; tablodaki farklı sütunlarda bulunan kriterleri karşılama derecesine göre (Eksik: 0 Düsük: 1 Orta: 2 Yüksek: 3) puanlanmıştır. Tabloda kullanılan puanlama sistemi aynı zamanda projeler konusunda süreç boyunca gözlemlenen verileri de sayısallaştırmaya yardımcı olan sonuçlar ortaya koymaktadır.

\begin{tabular}{|c|c|c|c|c|c|c|c|c|}
\hline KRITERLER & $\begin{array}{l}\text { MINIMUMM } \\
\text { MÜDAHALE }\end{array}$ & KORUMA & $\begin{array}{c}\text { KORUMA } \\
\text { ARAŞTIRMASI }\end{array}$ & $\begin{array}{l}\text { GELENEKSEL } \\
\text { YAPIM } \\
\text { TEKNIKLERI }\end{array}$ & $\begin{array}{l}\text { MODERN YAPIM } \\
\text { TEKNIKLERI }\end{array}$ & IÇ MEKAN ALGISI & MIMARI ELEMAN VURGUSU & YAKIN ÇEVRE \\
\hline KISA TANIM & $\begin{array}{l}\text { Yeni işlevle } \\
\text { birlikte yapiya } \\
\text { ağır bir yük } \\
\text { getirilmemesi }\end{array}$ & $\begin{array}{l}\text { Özgün tarihi dokunun } \\
\text { korunması adina uygun } \\
\text { yaklaşımın gelistiriilmesi, tercih } \\
\text { edilen müdahalle teknik ve } \\
\text { yöntemleri, yeniden } \\
\text { işlevvendirmede yapilan } \\
\text { çağdas eklerin özgün yapı ile } \\
\text { dengesi }\end{array}$ & $\begin{array}{l}\text { Rölöve ve } \\
\text { Restitüsyon } \\
\text { verilerinin } \\
\text { incelenmesi }\end{array}$ & $\begin{array}{l}\text { Geleneksel yapım } \\
\text { tekniklerini tekraa } \\
\text { ederek yapilan } \\
\text { yeniden } \\
\text { işlevlendirme } \\
\text { müdahalesi }\end{array}$ & $\begin{array}{l}\text { Modern yapım tekniği } \\
\text { ve malzemesi tercih } \\
\text { edilerek yapılan yeniden } \\
\text { işlevlendirme } \\
\text { müdahalesi }\end{array}$ & $\begin{array}{l}\text { Yapının mekansal } \\
\text { özelliklerinin, pencere- } \\
\text { kapı açıklıkları vb. özgün } \\
\text { niteliklerinin iç } \\
\text { mekanlarda } \\
\text { anlaşıllabilir/okunabilir } \\
\text { olması }\end{array}$ & $\begin{array}{l}\text { Yapıya ait özgün mimari bir } \\
\text { elemanın tasarımın ana öğesi } \\
\text { haline getirilmesi }\end{array}$ & $\begin{array}{l}\text { Tarihi dokuya uygun } \\
\text { bir yaklaşım geliştirme }\end{array}$ \\
\hline Ö.1 & 3 & 3 & 0 & 0 & 3 & 2 & 1 & 0 \\
\hline Ö.2 & 2 & 1 & 0 & 0 & 3 & 2 & 0 & 2 \\
\hline Ö. 3 & 2 & 2 & 0 & 0 & 3 & 2 & 0 & 3 \\
\hline Ö.4 & 2 & 2 & 0 & 0 & 3 & 2 & 3 & 2 \\
\hline Ö.5 & 1 & 2 & 0 & 0 & 3 & 1 & 0 & 0 \\
\hline Ö.6 & 1 & 1 & 0 & 0 & 3 & 1 & 0 & 1 \\
\hline 0.7 & 1 & 3 & 0 & 0 & 3 & 2 & 2 & 2 \\
\hline Ö.8 & 1 & 1 & 0 & 0 & 3 & 1 & 1 & 0 \\
\hline Ö.9 & 1 & 2 & 1 & 0 & 3 & 2 & 3 & 0 \\
\hline Ö.10 & 1 & 2 & 0 & 0 & 3 & 1 & 0 & 1 \\
\hline Ö.11 & 1 & 1 & 0 & 0 & 3 & 1 & 0 & 0 \\
\hline 0̈.12 & 1 & 1 & 1 & 0 & 3 & 1 & 2 & 0 \\
\hline 0.13 & 2 & 2 & 0 & 0 & 3 & 1 & 0 & 2 \\
\hline Ö.14 & 1 & 1 & 0 & 0 & 3 & 1 & 0 & 0 \\
\hline Ö.15 & 3 & 2 & 0 & 0 & 3 & 2 & 3 & 1 \\
\hline
\end{tabular}




\subsubsection{Metinlerin analizi}

Proje analiz çalışmasına destekleyici olması amacıyla, derse katılım gösteren tüm öğrencilerden dönem sonunda mezuniyet stüdyosu deneyimlerini paylaştıkları metinler istenmiştir. Aslında her metin açık uçlu bir soru niteliğindedir. Bu metinler aracılığı ile öğrencilerin deneyimlerinden faydalanarak süreci tekrar değerlendirmek amaçlanmıştır. Yazılması istenilen metinlerde; öğrencilerin stüdyo kapsamında kendilerine verilen tarihi yapı ile koruma çerçevesinde kurduğu ilişki ve hassasiyeti tekrar düşünmeleri, tarihi çevre ve yapıda çalışmanın zorlukları ile yüzleşmeleri istenmiştir. Böylece öğrencilerin kendilerini bu alanda ne derece donanımlı hissettiklerinin değerlendirilmesi amaçlanmıştır.

Yapılan çalışmada 15 öğrencinin birbirinden bağımsız hazırladığ 1 metinlerden elde edilen 3000 kelime, etiket bulutu (tag clouding) analizi ve içerik analizi olmak üzere nicel ve nitel araştırma yöntemlerinin beraber kullanıldığ 1 bir metodoloji ile değerlendirilmiştir.

Ön değerlendirme aşamasında; niceliksel analiz yöntemlerinden biri olan etiket bulutu (tag clouding) yöntemi kullanılmıştır. 2000'lerin başında ilk kez Jim Flanagan tarafından bir sunum biçimi olarak kullanılan yöntem ile, 3000 kelimelik metindeki ilk göze çarpan örüntüleri tanımlamak amaçlanmıştır. Zhou ve Benel $(2008,24)$ kelime bulutunun belirli bir metin içinde ortak ve sıkça tekrar eden temaların tanımlanması açısından pratik ve işlevsel bir yöntem olduğunu vurgulamaktadır.

Öğrencilerden toplanan 3000 kelimelik metindeki kelimeler kullanım sıklıkları ve ağırlıklarına göre sıralanmıştır. Türkçe'de sık kullanılan ve bundan dolayı kelime frekans analizinde dikkate alınmaması gereken sözcükler (ama, fakat, bir, göre, ve, veya, ile, $b u$, şu, kadar vb.) ayıklanarak söz konusu kelime bulutu oluşturulmuştur. Ortaya çıkan gösterimde, kelimelerin boyutları ve renk tonları önem derecelerine göre değişmektedir. Tablo 3 'te görüldüğü üzere; öğrencilere mezuniyet projesine dair fikirleri sorulduğunda en sık kullandıkları kelimeler "eski”, "yeni”, "tarihi”, "koruma”, "kimlik",

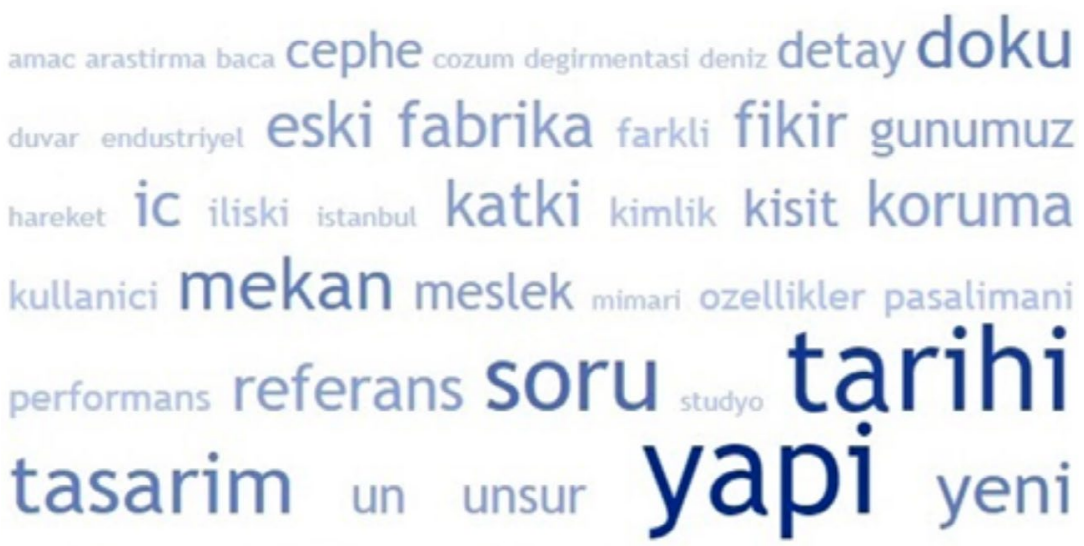

\section{yonlendiren Zaman zarar zorlayan}

“cephe”, “duvar”, “detay”, “doku”, “iç”, "ilişki", "kısıt", ve "mekân” dır.

Tablo: 3

Etiket Bulutu Yöntemi Kullanılarak Yapılan Metin Analizi Sonuçları.
Etiket bulutu çalışması bir ön analiz niteliğinde olup bir sonraki aşama olan içerik analizi için alt başliklar elde etmek üzere yapılmıştır. İçerik analizi ile amaçlanan metinlerden elde edilen verileri derinlemesine inceleyerek ana kavram ve ilişkilere ulaşmaktır (Creswell 2007; Creswell 2009). Öğrencilerden toplanan metinler iki araştırmacı tarafından bağımsız olarak incelenerek gözlemlenen farklı olgulara göre farklı gruplara ayrılmıştır. Daha sonra bu olgular karşılaştırılarak, her gruba belirli başlık verilmiştir. Belirlenen ortak başlıklar altında kategorize edilen metinlerin daha derin bir incelemeye tabii tutulması ile fark edilemeyen kavram ve ilişkilere ulaşmak amaçlanmıştır.

Açık uçlu soruya verilen cevaplarda yapılan içerik analizine göre; tüm öğrencilerin öncelikle çalıştıkları tarihi yapıya vurgu yaptıkları görülmüştür. Çalışma konusu verilirken dikkat çekilen, dönem boyunca seminerler ve jürilerde altı çizilen tescilli kültür varlığı bir yapıya müdahalenin belirli bir hassasiyet gerektirdiği konusunda öğrencilerin tamamının farkındalıklarının yüksek olduğu anlaşılmıştır. Ancak müdahale söz konusu olduğunda uygun yöntemleri tasarım kararlarıyla bütünleştirme konusunda zorluk çekmişlerdir. Uygun bir yöntem arayışındaki öğrencilerin büyük çoğunluğun "yerinde mevcut olan tarihi dokunun korunması" ve/veya "tarihi yap1nın mevcut mimari elemanlarının ön plana çıkarılması" istekleri üzerinde yoğunlaştıkları görülmektedir.

76 sayı 34, Kasım 2021 
Gerek koruma alanındaki bilgi birikimleri gerekse süreç boyunca altı çizilen hassasiyetler doğrultusunda öğrencilerin tarihi yapı için geliştirdikleri en temel koruma yaklaşımı yerinde mevcut olan tüm dokunun sürdürülmesi yönünde olmuştur. Tasarımlarını geliştirirken mevcut olan dokunun zarar görmemesi, yok olmaması yönünde çaba göstermişlerdir. Ancak bunu yaparken ve tarihi yapıyı değerlendirirken genellikle yapının günümüze ulaşamamış unsurlarını göz ardı ettikleri görülmüştür. Mevcut doku ve yapıdaki izler üzerinden tarihi yapının bütününü anlama ve bütüncül bir koruma yaklaşımı geliştirme çalışmaları yetersiz kalmıştır.

Koruma konusunda bir diğer genel yaklaşım ise tarihi yapının mevcut mimari öğelerinin tasarım anlayışı ile ilişkilendirilerek ön plana çıkarılması yönünde olmuştur. $\mathrm{Bu}$ yaklaşım da yine ilk olgu ile oldukça benzer olarak alanda mevcut olan, gözle görülen ve dikkat çeken bir elemanın sürdürülmesi yönündedir. Ancak bu noktada da benzer bir eksiklik göze çarpmaktadır. Tasarım anlayışı içerisinde dikkat çekilmeye çalışılan mimari eleman konusunda yeterli bilgi sahibi olmadan, tarihi yapının özgün plan ve programı içerisindeki yeri yeterince araştırılmadan bir yaklaşım geliştirilmeye çalışılmıştır.

Her iki olguda da karşımıza çıkan bu eksikliğin, tarihi yapının tarihsel gelişimi, öyküsü, özgün plan ve programı konusunda nasıl bir araştırma yürütülmesi gerektiği konusunda yeterli bilgi sahibi olunmaması durumundan kaynaklandığı gibi mezuniyet projesi içerisinde bu alana yeterince zaman bulamamaktan da kaynaklandığı düşünülmektedir.

\subsection{Bulgular ve Değerlendirmeler}

Öğrencilerin tamamı tarihi bir yapıda çalışıyor olmanın bilinci ile gerekli hassasiyetleri göstermeye çalışarak proje sürecine başlamışlardır. Dönem başında yapılan seminer dizisi ve yapının bulunduğu yere gerçekleştirilen alan çalışması bu bilincin artmasına yardımcı olmuştur. Öğrencilerin yapı için yeniden kullanım önerilerini geliştirmeden önce yapının tarihsel gelişimi üzerine derin bir araştırma yapmalarının son derece önemli olduğu vurgulanmıştır. Farklı disiplinlerden bir araya gelen jüride koruma alanında uzman kişilerin bulunuşu öğrencilerin bu konudaki hassasiyetlerini geliștirmesine dönem boyunca katkı sağlamıştır.

Ancak, mezuniyet projesi kapsamı gereği öğrencilerin öğrenim hayatı boyunca edindiği tüm bilgi ve birikimi dersin istenilen çıktıları üzerinden dönem sonunda yansitmaları beklenmektedir. Bu nedenle öğrenciler, rölöve çizimlerini hazır olarak aldıkları tarihi yapı hakkında detaylı bir tarihsel gelişim ve restitüsyon araştırması yapacak yeterli zamanı bulamamışlardır. Öğrencilerin mezuniyet projesinin diğer gereklerini yerine getirebilmek adına bu alana yeterince vakit ayıramadıkları gözlenmiştir.

Öncelikle yapının mevcut durumu göz önünde bulundurulduğunda; yapının verilen yeni işleve göre yeniden kullanılabilmesi için günümüze ulaşamayan mekânsal ilişkileri, iç duvarları, taşıyıcı sistemi vb. öğeleri yerine iç mekâna yönelik yeni bir yaklaşım geliştirmek gerekli olmuştur. Öğrencilerin tamamının yalnızca yığma taş duvarları günümüze ulaşabilen tarihi yapıya çağdaş yapım teknikleri ve malzemelerle müdahalede bulunacak şekilde öneriler geliştirdikleri görülmektedir. Tarihi yapıya yapılacak müdahalelerde yapilan yeni ekin, eklenen yeni malzemenin ayırt edilebilir olması gerekir. Öğrencilerin geleneksel yapım tekniği ve malzemelerini tekrar etmeyen yaklaşımları yapıya yapılan müdahalelerin tarihi dokudan ayırt edilebilme imkanını arttırmaktadır. Bir öğrencimiz yaptığı müdahaleyle tarihi yapıyı daha da görünür kılma amacını şu şekilde özetlemiştir : "Çalıştığımız yapı geçmişten gelen bir tarihe, hikayeye ve dokuya sahip. Ben projemde bu simgesel yapıyı daha da görünür kılmak, herkes tarafından fark edilmesini sağlamak için çağdaş malzemeler kullanarak modern şeffaf bir ek tasarladım." (Şekil 5).

Dönem boyunca öğrencilere tarihi yapının restorasyonu sırasında minimum müdahalede bulunmanın önemi vurgulanmıştır. Restorasyon aşamasında yapılan müdaha- 


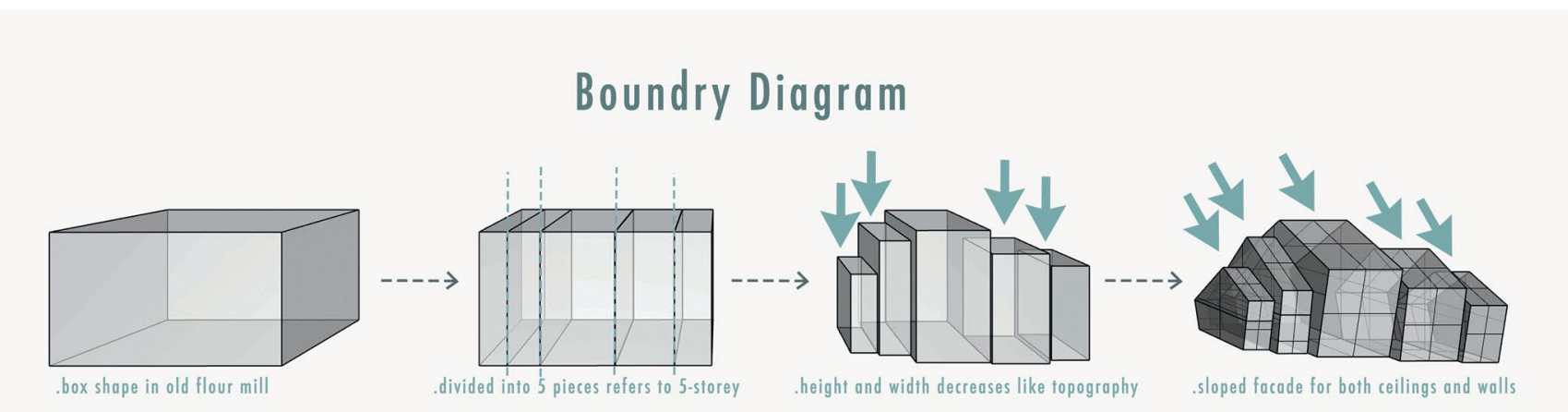

lenin geri döndürülebilir olması konusunun altı çizilmiştir. Ancak bu konu göz önünde bulundurularak geliștirilmeye çalışılan projeler arasında ancak birkaç önerinin bunu başarılı bir biçimde karşıladığı görülmektedir.

Pek çok projede tasarımların çıkış noktası tarihi yapı, tarihi yapının bulunduğu çevre ve yapının çevresiyle kurduğu ilişki olmuştur. Öğrenciler öncelikle tarihi yapının bulunduğu çevre ile ilgili ayrıntılı araştırma yapmışlardır. Yapılan araştırmalar doğrultusunda mevcut doku daha iyi analiz edilirken kimi öneriler mevcut dokudaki izlerden referans alarak gelişmiştir.

Yapının arazideki konumlanışı, bitişik nizam yapılarla ilişkisi, girişleri araziye ve yapıya yaklaşımda alınan kararlar için referans oluşturmuştur. Öğrencilerimizden biri tasarım fikrini anlatırken yapı ve yakın çevresinin araziye konumlaşına değinmiştir: 'Üsküdar'dan Kuzguncuk'a doğru yürürken eskizler yapıp fotoğraflar çekmiştim. Dikkatimi çeken nokta topografyanın sanki birike birike yığılmasıydı. Ana mekânlarımı oluştururken bu özellik bana yardımcı oldu" (Şekil 6).

Mevcut yapının özellikleri de tasarım kararlarını etkileyen en önemli unsurlardan olmuştur. Tasarımlar geliştirilirken tarihi yapının cephesi, özgün açıklıkları, döșeme açıklıkları, farklı birimleri arasındaki mekânsal ilișkileri dikkate alınmıștır. Bir ögrencimiz ise yapıdaki izleri bir tasarım konseptine dönüştürmeyi amaçladığını söylemiştir: "Bir un fabrikasının ana öğesi değirmen taşlarıdır. Değirmen taşının temel işlevi; unu döndürülerek ve bastır1larak istenilen şekilde ufalamaktır, Mekân içindeki kütleleri oluştururken bu işleyişten yararlanmak istedim. (Sekil 7)."

Bu konudaki vurguları değişmekle birlikte tarihi yapıya ait özgün bir mimari elemanın iç mekân tasarımın ana öğesi haline dönüştürme isteği beş farklı öğrenci projesinde görülmüştür. Başka bir öğrencimiz projesinin ana fikrini anlatırken mevcut yapıdaki referanslara bu bağlamda değinmiştir: "Tasarım fikrimi geliştirirken beni yönlendiren en önemli referans, çalıştı̆̆ımız tarihi yapıydı. Paşalimanı Un Fabrikasını incelemeye girdiğimiz ilk an yapının duvarları beni çok etkiledi. Geçmişten günümüze kalan tek ortak nokta bu tarihi duvarlardı ve bu duvarlar içerisinde çok farklı anılar hapsolduğunu hissetmiştim."

Endüstri mirası bir yapının mekânsal ilişkilerini ve işleyişini daha iyi anlatabilmek
Şekil: 5

Tarihi yapıyı ön plana çıkarmak amaçı tasarlanan seffaf kütleler, Başak Saygı isimli ögrenciye ait çalışma (Selin Üst fotoğraf arşivi).
Sekil: 6

Yapı ve yakın çeure analizlerinin iç mekân kütle oluşumuna yansıması, Elnur Kayaoğlu isimli ögrenciye ait çalışma (Selin Üst fotoğraf arşivi).
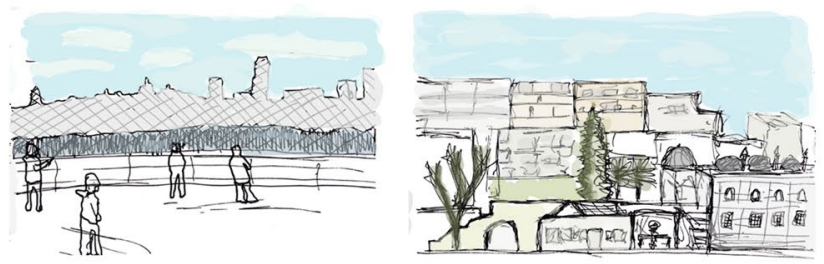
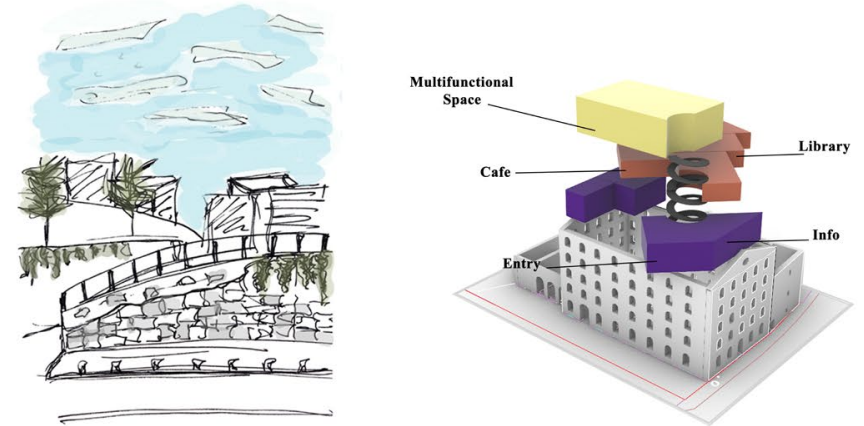
Şekil: 7

Yapıdaki değirmen taşları izleri üzerine yapılan arastirma, Izel Kavuzlu isimli öğrenciye ait çalışma (Selin Üst fotoğraf arşivi).
Sekil: 8

Fabrikanın Ambar Mekânındaki Tuğla Kolonlar (solda) ve bacası (sağda), (Selin Üst fotoğraf arşivi).

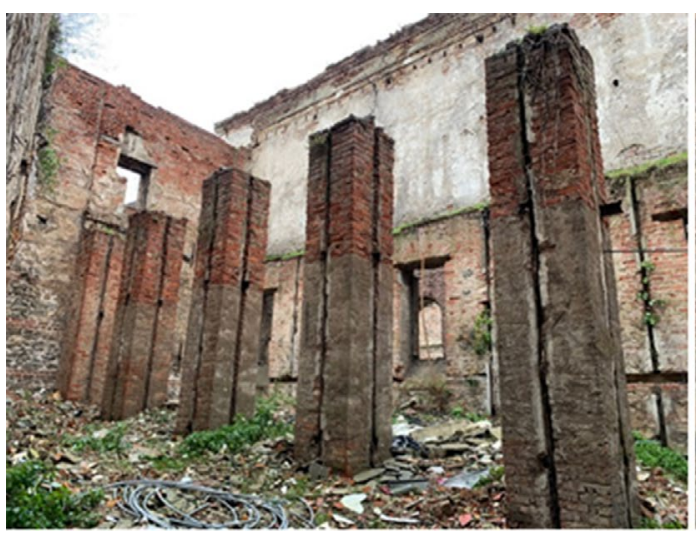

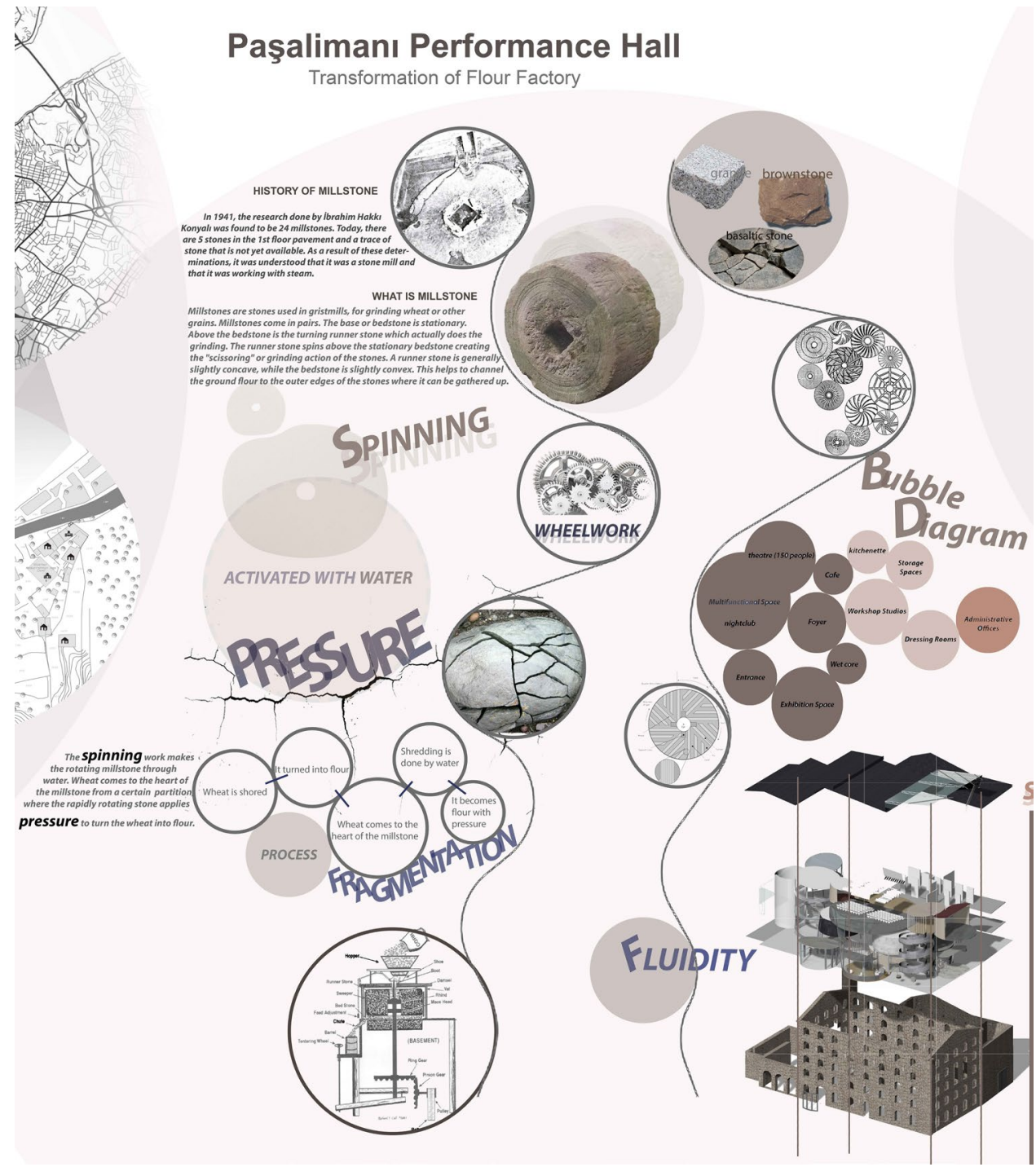

adına iç donanımlarıyla birlikte korunması önemlidir. Mezuniyet projesinde üzerinde çalışılan tarihi un fabrikası yapısı ise yalnızca dış duvarları ile günümüze ulaşabil-

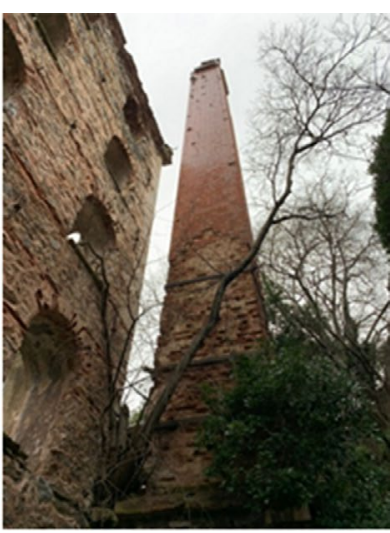

miştir. Yapının içindeki bölücü duvarlar ve döşemeler ile iç donanımlar günümüze ulaşıncaya dek varlığını sürdürememiş, yok olmuştur. Ancak yapıda üretimin baca, depolama birimleri (ambar) gibi yap1sal öğeler ve yok olan diğerlerine ait izler bulunmaktadır (Şekil 8). Dönem boyunca yap1 ve yapının tarihçesi konusunda yap1lan araştırmalar doğrultusunda öğrenciler söz konusu referanslardan yola çıkarak projelerini geliştirmişlerdir.

Bir öğrencimiz iç mekân tasarımında tarihi yapının günümüze ulaşabilen öğelerinden bacayı öne çıkartmak istediğini belirtmiştir: "Tasarım fikrimi oluştururken tarihi yapının geçmişten gelen izlerini referans devam ettiği döneme yönelik ipucu veren 


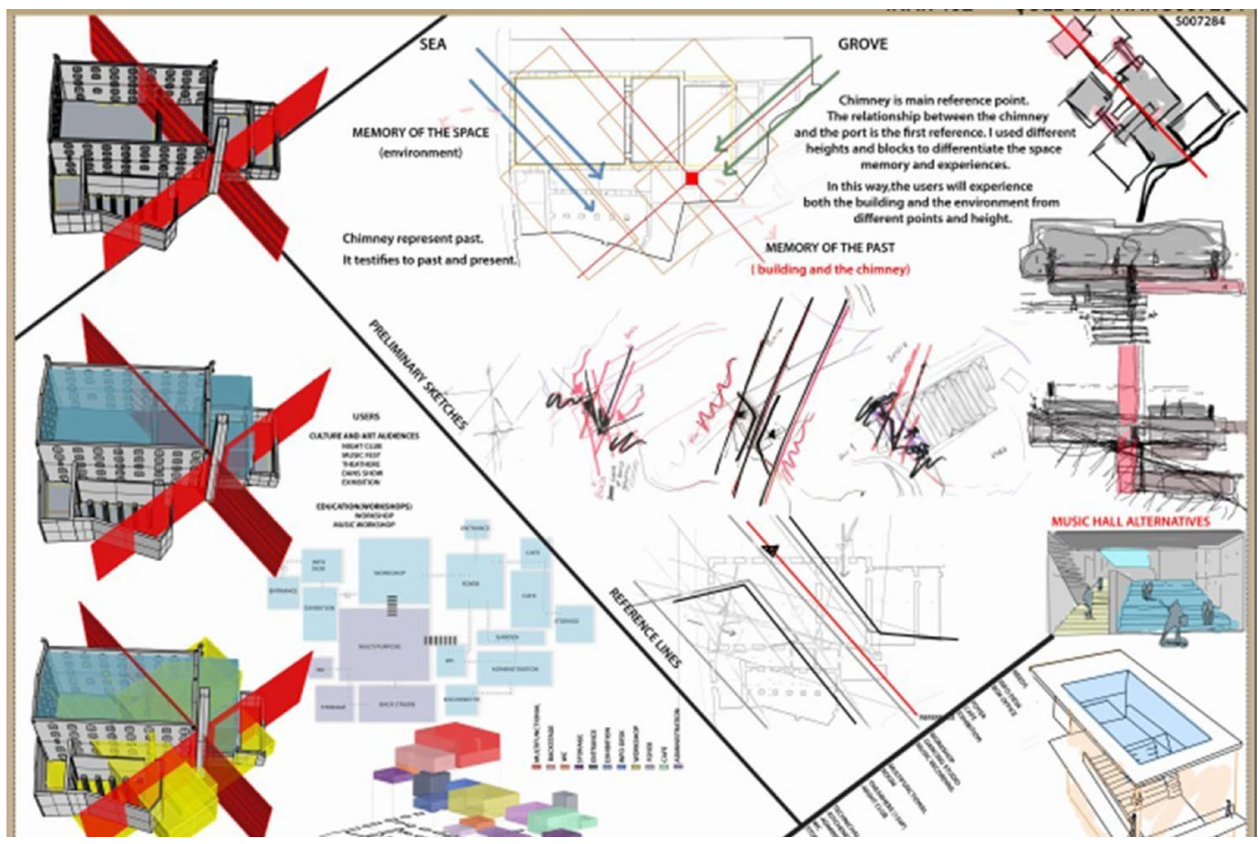

alarak ilerledim...Ana öğe olan bacayı öne çıkarmayı amaçladım" (Şekil 9).

Geliştirilen önerilerin çoğunluğunda tarihi yapının günümüze ulaşabilen dış duvarlarını sergileme konusunda iç mekânda özel bir hassasiyetin olduğu söylenebilir. Bunun için öğrencilerin önerilerinde tarihi yapının duvarlarını sıvasız olarak bırak- mak veya iç mekânda galeri boşlukları oluşturarak yapıyı daha iyi sergilemeye çalışmak gibi çabalarının olduğu gözlenmiştir. Öğrencilerimizden biri yaptığ tasarımla tarihi yapıyı sergilemeyi amaçladığını vurgulamıştır: "Yeni bir fonksiyon kazandırdığımız tarihi yapıya şeffaf ekler tasarlamak istedim. Böylece tarihi yapının yeni yapı üzerinde de yansıya-

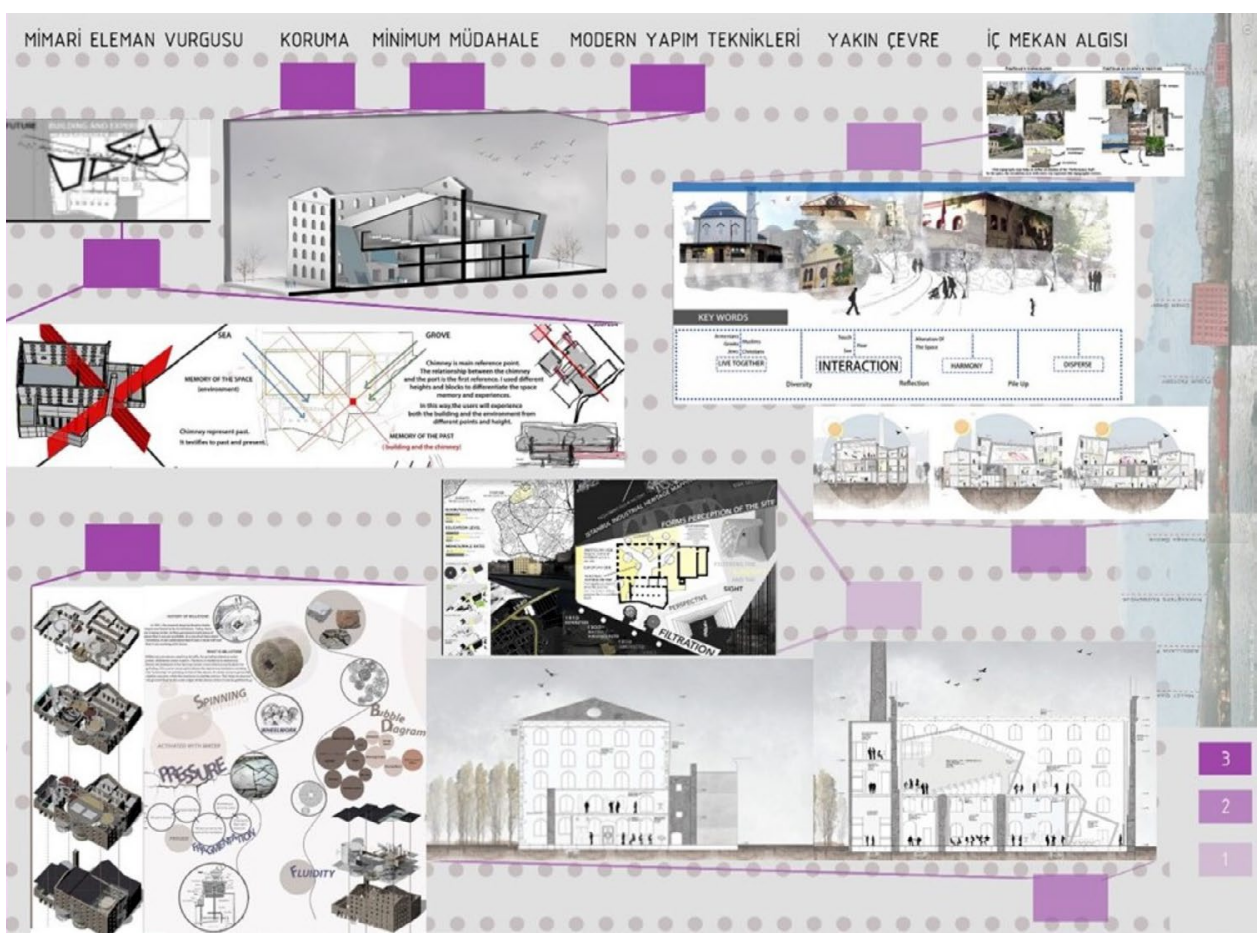

Tablo: 4

Değerlendirme kriterleri doğrultusunda yapilan proje analiz genel tablosu.

Yapının bacasının if mekân tasarımına yön verdiği eskizler, şule özpınar isimli öğrenciye ait f̧alısma (Selin Üst fotoğraf arşivi).

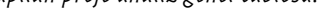


rak yaşamaya devam etmesini sağlamak önceliğimdi."

Çalışma kapsamında yapılan proje analizi sonuçları Tablo 2 ve Tablo 4 birlikte incelendiğinde daha net görülebilmektedir. Öğrencilerin tamamının bitirme projesinin gereklerini yerine getirebilmek adına tarihi yapının rölöve ve restitüsyon verilerinin incelenmesi konusuna yeterince zaman ayıramadıkları görülse de koruma, minimum müdahale, iç mekân algısı, yakın çevre analizi, mimari eleman vurgusu gibi değerlendirme kriteri olarak belirlenen farklı başlıklarda tasarım süreci boyunca birbirinden farklı hassasiyetler geliştirdikleri gözlenmektedir (Tablo 2; Tablo 4).

\section{Sonuç}

Kültürel miras bakımından oldukça zengin olan ülkemizde tarihi yapılar iç mimarların meslek hayatlarında karşılaşacakları yapı örneklerinin önemli bir bölümünü oluşturmaktadır. İç Mimarlık disiplini, mevcut yapıların korunmasında yapının değerinin ve durumunun doğru şekilde analiz edilmesinden ve doğru çözümler üretilmesinden sorumludur (Brooker ve Stone 2010). Dolay1s1yla, iç mimarlık eğitiminin koruma olgusuna karşı mesleki yeterliliklerini geliştirmekte rolü büyüktür. Bu bilinç lisans düzeyinde başlamalı, yüksek lisans ve doktora düzeyinde koruma odaklı programlar ile desteklenmelidir.

Özyeğin Üniversitesi, İç Mimarlık ve Çevre Tasarımı Bölümü, 2019-2020 bahar yarıyılı mezuniyet projesinde verilen tarihi yapının yeniden işlevlendirilmesi konusu ve bu konuya yönelik öğrencilerin yaklaşımları üzerinden, iç mimarlıkta koruma öğreniminin yeri ve önemi konusunda birkaç temel değerlendirme yapmak mümkündür.

Uluslararası araştırmaların da altını çizdiği gibi koruma bilincinin artırılması adına öğrencinin yalnızca stüdyo dersi kapsamında değil öğrenim hayatı süresince bu alanda desteklenmesi önemlidir. Bu doğrultuda öğrencilerin programlarına eklenecek zorunlu ve seçmeli dersler ile koruma farkındalıklarının arttırılması gereklidir. Bunun yanı sıra öğrencilerin tarihi bir yapı ile ilişkili iç mekân projelerini yalnızca mezuniyet projesinde değil bu aşamaya gelmeden önceki stüdyo derslerinde de farklı ölçek ve gereklilikler üzerinden deneyimlemiş olması faydalı olacaktır. Tasarım eğitiminin temel problemi olarak birçok farklı araştırma ve yayında belirtilen öğrencilerin lisans eğitimi süresinde edindikleri bilgiyi tasarım stüdyolarına aktarmakta çektikleri zorluk bu çalışmada da ön plana çıkan maddelerden bir diğeri olmuştur. Benzer bir problem hemen hemen tüm derslerde yaşanmakla birlikte çok boyutlu bir yaklaşım gerektiren tasarım stüdyolarında özellikle ön plana çıkmaktadır. Her dersin belirli bir içeriği ve dönem sonunda, yani kısıtlı bir zaman içerisinde, tamamlanması beklenen çıktıları bulunmaktadır. İç Mimarlık ve Çevre Tasarımı Bölümü mezuniyet projesi özelinde düşünüldüğünde; öğrencilerin 14 haftalık bir zaman içinde, verilen tarihsel bağlamı analiz edip tasarım programını yeniden işlevlendirmeye göre yorumlayarak, kavramsal bir çerçeve oluşturması ve oluşturulan kavramsal yaklaşım dahilinde çok boyutlu bir tasarım problemine mesleğin gereklerine ve ilgili yönetmeliklere göre çözüm üretmesi beklenmektedir. Bu beklenti ve hedeflere yoğunlaşan öğrenciler çoğu zaman lisans eğitimi boyunca diğer derslerde edindikleri bilgi birikiminin önemli bir bölümünü projelerine yansıtma firsatı bulamamışlardır. Parçaları bir araya getirmesi beklenen taraf elbette öğrenciler olmakla birlikte öğretim üyelerinin süreci yönlendirebilecek çeşitli formüller üzerinde çalışmaları da faydalı olacaktır. Örneğin; teorik derslerin stüdyo dersleriyle entegre olmasını sağlayacak hibrit çalışmalar öğrencilerin teorik olarak öğrendiği bilgileri uygulamaya yansitmas1 açısından verimli olacaktır. Tarihi bir yapının yeniden işlevlendirilmesi üzerine odaklanan İç Mimarlık ve Çevre Tasarımı Bölümü Mezuniyet Stüdyosunun; bölümün lisans programında koruma alanında verilen derslerle entegre bir biçimde yürütülmesi önerilebilir. Böyle bir yaklaşım ile; öğrencilerin lisans eğitimlerinin 6. döneminde zorunlu ders olarak aldıkları Architectural Conservation and Surveying (Mimari Koruma ve Rölöve) dersi kapsamında 
üzerinde çalıştıkları proje konusuna Mezuniyet Stüdyo dersinde de devam edilmesi sağlanabilir. Bu durum öğrencilere verilen konunun hem koruma hem de yeniden işlevlendirme ile getirilen çağdaş iç mekân tasarımı boyutunun ayrıntılı olarak tartışıma olanağı sağlamasının yanı sıra tarihi bir yapının korunması konusunda öğrendikleri teorik bilgiyi uygulamaya koymaları konusunda firsat tanımaya, koruma alanındaki farkındalıklarını bir kat daha arttırmaya katkı sağlayacaktır.

Dönem sonunda teslim edilen projeler üzerinden yapılan analizlere göre farklı yaklaşımlar geliştiren tüm öğrencilerin tarihi yapının korunması konusunda belirli bir hassasiyet içerisinde oldukları görülmektedir. Yapının bulunduğu tarihi dokudan referans alan ve tasarımını bu yönde geliştiren öğrenciler çoğunlukta olmuştur. Yine öğrencilerin birçoğunun yaklaşımlarını anlatırken tarihi yapıyı veya tarihi yapının bir parçasını, öğesini ön plana çıkarmaya çalıștıkları görülmektedir. İç mekân tasarımlarında tarihi yapının özgün duvarlarının, cephe boşluklarının daha iyi algılanmasını sağlayacak seçeneklere yönlendikleri gözlenmektedir. Bütün bunlardan yola çıkarak öğrencilerin kültür mirasının korunması konusunda belirli bir farkındalık düzeyinde oldukları söylenebilir. Ancak tarihi yapı ile kurdukları ilişkiyi geliştirebilmek adına yukarıda da önerilen tarihi yapı ve tarihi doku ile ilgili lisans eğitimleri boyunca daha fazla çalışma yapmaları, farklı derslerin birbirleriyle entegrasyonu ile yapılabilecek pratikler katkı sağlayacaktır

\section{Kaynakça}

Ahunbay, Z., Tanyeli, G. ve Salman, Y. (Ed.). (2002). Mimarlık Ĕ̆itiminde Koruma: Mimarlık Okullarının Lisans Programlarında Tarihi Çevre Koruma ve Restorasyon Ĕ̆itimi, Doğan Kuban Semineri 2000, İstanbul: TMMOB Mimarlar Odası İstanbul Büyükkent Şubesi.

Brooker, G. ve Stone, S. (2010). What Is Interior Design, Switzerland: RotoVision SA.

Clarke, N., Zijlstra, H. ve Jonge, W. D. (2019). Education for Adaptive Reuse-The TU Delft Heritage and Architecture Experience. Docomomo Journal, 61(3), 67-75.

Creswell, J. W. (2007). Qualitative inquiry and research design: Choosing among five approaches. Thousand Oaks, California: Sage.

Creswell, J. W. (2009). Research Design: Qualitative, quantitative, and mixed Methods approaches (3. bask1). Thousand Oaks, California: Sage.

Embaby, M. E. (2014). Heritage conservation and architectural education:"An educational methodology for design studios”. HBRC Journal, 10(3), 339-350.

International Council on Monuments and Sites. (1964). Venedik Tüzüğ̈̈. www.mo.org.tr/mevzuatDocs\%5CVenedik_Tüzük.doc

Jokilehto, J. (2007). An international perspective to conservation education. Built environment, 33(3), 275-286.

Karakul, Ö. (2018). Designing the Museum of Turkey"e s Intangible Cultural Heritage: A Studio Experience of Interior Architectural Design. Milli Folklor-International and Quarterly Journal of Cultural Studies, 30, 140-157.

Karakök, E. Ç. ve Gökarslan, A. B. (2017). Tarihi Dokuda "Çağdaş Ek" Kavramının Atölye Ortamında Deneyimlenmesi: Mass' Workshop 2015. Tasarım+Kuram Dergisi, 13(24), 54-78.

Kariptaş, F. S. (2012, Kasım). Üsküdar'da Endüstri Mirası Örneği Bir Değirmen Yapısı: Üsküdar Pașalimanı Değirmeni. Sözlü Sunum, Uluslararası Üsküdar Sempozyumu VII (109-114). İstanbul.

Karslı U. T. ve Fitoz, İ. (2018). Notes on an Adaptive Reuse Experience in Design Studio, Online Journal of Art and Design, 6(3), 127-142.

Kapp, P.H., Bricher, L.W. ve Hoyos, L.H. (2014). Challenging the assumption about a direct relationship between historic preservation and architecture in the United States. Preservation Education: Sharing Best Practices and Finding Common Ground içinde (s. 175-191). University Press of New England; Hanover.

Müller-Wiener, W. (1992). 15-19. Yüzyıllar arasında Istanbul'da Imalathane ve Fabrikalar. Osmanlılar ve Batı Teknolojisi, Yeni Araştırmalar, Yeni Görüşler içinde (s.53-120). İstanbul: İstanbul Üniversitesi Edebiyat Fakültesi Yayını.

Onay, N. S. (2015). A framework to analyse historic buildings and interiors. Structural Studies, Repairs and Maintenance of Heritage Architecture XIV, 153, 183-194.

Onay, N. S. ve Yazıcıoğlu, D. A. (2015). Functional Continuity in Adaptive Reuse of Historic Buildings: Evaluating a Studio Experience. American Journal of Educational Research, 3(6), 674-682.

Orbasli, A. ve Whitbourn, P. (2002). Professional Training and Specialization in Conservation: An 
ICOMOS Viewpoint. Journal of Architectural Conservation, 8(3), 61-7.

Özyeğin Üniversitesi İç Mimarlık ve Çevre Tasarımı Bölümü Ders İçerikleri. (2019, 11 Temmuz). Özyeğin Üniversitesi, https://www.ozyegin. edu.tr/tr/ic-mimarlik -ve-cevre-tasarimi/lisans/ ders- icerikleri.

Salama, A. (1995). New trends in architectural education: designing the design studio. Raleigh, NC, USA: Tailored Text Publishers.

Salama, A. (2015). Spatial design education: new directions for pedagogy in architecture and beyond. Farnham Surrey, England ; Burlington: Ashgate.

Sanza, P. (2015, Eylül). Reclaiming The Past: Adaptive Reuse in the Design Studio. Sözlü Sunum, Envisioning Architecture: Image, Perception and Communication of Heritage Conference, (439-449). Lodz.

Schön, D. A. (1985). The design studio: An exploration of its traditions and potentials. London: RIBA Publications.

Schön, D. A. ve Wiggins, G. (1992). Kinds of seeing and their functions in designing. Design Studies, 13(2), 135-156.

Wells, J. C. (2018). Challenging the assumption about a direct relationship between historic preservation and architecture in the United States. Frontiers of Architectural Research, 7(4), 455-464.

Wiener, W. M. (1992). 15-19. Yüzyılları Arasında İstanbul'da İmalathane ve Fabrikalar. Osmanlılar ve Batı Teknolojisi Yeni Araştırmalar Yeni Görüşler (s.53-120), İstanbul: İstanbul

Üniversitesi Edebiyat Fakültesi Yayınları.

Zhou, C. ve Benel, A. (2008, Mayis). From the crowd to communities: New interfaces for social tagging Sözlü Sunum, COOP 2008: Proceedings of the 8th International Conference on Designing Cooperative Systems, (242-249). Carry-le-Rouet, Provence. 